\title{
THE WORLD SYSTEM IN CIVILISATIONAL CRISIS
}

\author{
Karim D. Crow
}

\begin{abstract}
Neoliberal financial-market capitalism has dragged the world into a crisis which threatens human civilisation as such. It is characterised by an extreme form of the combination of the expansion of production, transport and life-style, with on the other hand the destruction of its own foundations, and suffers from a crisis of social reproduction, societal integration, democratic identification and security. Climate destruction, resource wars, terror, the transformation of democracy into oligarchy, class divides, a new racism and fundamentalism are unavoidable. It therefore leads to a crisis of civilisation, and produces ever stronger elements of barbarism and authoritarian power, which can only be contained at ever greater expense.
\end{abstract}

\section{Introduction}

It is impossible to be sanguine amidst the severe continuing recession and worldwide financial and economic uncertainty proliferating since September 2008. Rather than searching for 'green shoots' we require historically informed critical perspectives on the actual real significance of this ongoing event and its implications for the near future. To expect a return to 'business as usual' - even with imposed government regulations and transparent standards for financial procedures - is dangerously naïve. If people cannot learn from misplaced hopes and delusions, it will only compound our difficulty in advancing effective pragmatic policies, particularly for meeting the human needs of developing Asian societies.

Carbon-based fuels are the world's greatest single commodity in volume and value traded on world markets - in 2007, the top ten consuming nations alone used a total of ca. 64 million bbl/day. With fossil fuels remaining the chief source both of energy and of environmental pollution, our era of the late twentieth to early twenty-first centuries may be termed the 'Carbon Age'. At this time of writing the headlines shout: "The Demise of the Dollar" (The Independent, 6 October 2009), announcing the intent of oil producing Arab states in the Gulf Cooperation Council (GCC - primarily Saudi Arabia, the United Arab Emirates, Kuwait and Qatar) to

* Karim D. Crow is Principal Research Fellow at IAIS Malaysia. 
stop pricing and trading their oil in US dollars within nine years by 2018. Central bank governors and finance ministers of the GCC states, China, Japan, France and Russia are agreed to non-dollar payments for oil, moving to replace the greenback by a 'basket of currencies' pooling the euro, yen, the yuan and a new unified GCC currency, and which appears set to draw in the Russian rouble, British pound sterling and Indian rupee. ${ }^{1}$ America's declining economic power flowing from global recession and imperial overreach assumes even greater symbolic magnitude with this coming move away from the dollar's hegemony as the dominant global reserve currency and motor of the international financial system. It prefigures a major reconfiguration of economic power relations. Significantly, the juxtaposition of China and rich Arab Gulf producers, in tandem with Japan and Russia, signals the reconfiguration of strategic power alignments within an emerging multipolar global order. This increasingly evident shift may magnify the likelihood of future clashes over resources and rivalry for influence between China and the United States with intensified competition for Middle Eastern oil. It should not be forgotten that behind the deceit over weapons of mass destruction with the Iraq invasion in 2003 the previous US administration under George W. Bush was primarily motivated by desire to secure access to oil resources viewed as indispensable to US global financial and military primacy.

The condensed overview offered here does not pretend to perform an autopsy or a vivisection on the global financial recession. Other studies in this volume provide food for thought on this complex and depressing web of motives and events. Our concern is with the historical, ideational and civilisational trajectories operating at a deep level, the buried movement of forces provoking surface currents. Uninformed opinion by unreflective observers sees only the obvious outward convulsions and tremors, while gradual shifting of tectonic plates over decades and centuries unexpectedly throws up a violent quake or destructive tsunami. A shock of the magnitude of this current global free market collapse provides the opportunity to take stock and assess deeper forces at work. But to learn its broader meaning and better understand its real implications is possible only by looking dispassionately when grasping the underlying trajectories of human ideas and societies. Such understanding requires us above all to comprehend our world today - this perplexing and violent world of late modernity - and how it has unfolded to its present situation fuelled by the power and action of master ideas and 'myths'. Chief among these are the ideas of reason and progress inherited from the thinkers of the eighteenthcentury European Enlightenment, coupled with its corollary rise of scientism and dissemination of technological advances. These form the ultimate background to the spread of the global Free Market advancing the political agenda of capitalist financial and ruling elites. A lack of awareness of the past undermines our ability to make sense of the present. 
Why is it important to go back over time and trace out intellectual and ideological trends at work over several centuries, in order to achieve a more adequate grasp of what is occurring today? The simplest answer, and the truest one, is that ideas matter: master ideas which condition and channel human thinking and political activity, human social and cultural achievements, and the global realities we share in common today. The generality of observers who pause to reflect upon the course of events over the past two decades might not find this assertion credible. Certain ideas reviewed here may actually strike them as incredible! Furthermore, the importance of critical historical understanding of today's global situation lies in the many peoples and societies who find their destiny inextricably tied to what leaders in Berlin, Paris, London, Washington, Tokyo, Beijing and Moscow perceive and understand. Post-colonial nation-states in Africa and Asia have been experiencing the transformations induced by globalisation bringing Euro-American domination in mercantile, military, financial and cultural spheres. In their search for realising their own authentic form of modernity, non-Western peoples are forced to come to grips with political, economic and civilisational values and forces imposed from without. Lacking a clear comprehension of the deeper currents shaping their era, without a better understanding of the actual forces and ideas sweeping the planet, the diverse peoples risk 'losing themselves' becoming alienated from their own proper values and ethos through a pervasive and irresistible 'occidentalisation'.

Significant questions about our emerging pluralist era must therefore be addressed from a longer term perspective informed by critical awareness of historical roots and trajectories. It is imperative to listen to cogent alternatives dissenting from reigning Euro-American schools of thought. The ideas of a major alternative voice will be briefly sketched below who validates the reality of a diversity of cultures with distinctive political and economic models. John Gray is an iconoclastic English thinker whose political philosophy offers a bold critique of the dominant neoliberal ethical, political and economic thinking and policies in the United Kingdom and the United States.

The Egyptian francophone Samir Amin² is a profoundly original political economist and tireless advocate of non-Western 'peripheral' alternatives to dominant capitalist economic theory and practice. Over many years he has developed a coherent interpretation of the rise and spread of capitalism, and paid close attention to its transformation and patterns of hegemonic dominance. He also offers detailed reflection on the pragmatic possibility of the contours of a new multipolar global order. Both Amiya Kumar Bagchi ${ }^{3}$ and Amartya K. Sen ${ }^{4}$ are eminent Indian economists whose welfare development theories have shaped contemporary thinking on the imperative to achieve human needs in social and political transformation. It is significant that these three eminent thinkers have paid close attention to the economic and cultural realities of India and China, as well as other Asian societies. 
Taken together along with John Gray, the ideas of these alternative voices affirm that differing societies realise their own distinctive modes of modernity by drawing on civilisational values and experiences deeply embedded within their own cultures.

We emphasise again that this concise presentation is intended to arouse thought and prompt reflection on wider civilisational implications of recent events. The reader should not uncritically imagine that by presenting these views we are blessing them with unqualified approval. Our motivation is primarily to prompt critical reflection upon ideas in historical perspective which government officials as well as the official media frequently ignore or marginalise. The emphasis on critical reason was an essential Enlightenment motivation, and prepared the way for the advent of modernity.

\section{The Enlightenment and Modernity}

Modernity arose in Western Europe about three centuries ago with the rise of new social classes of intellectuals who sought to free themselves from the grip which traditional Christian churches exercised over men's minds. There emerged an audience of educated readers eager to absorb new ideas promising an egalitarian social order through ending feudal monarchic privileges, as well as replacing authoritarian dogmas of the Church with rational principles in harmony with the uniformity of nature displayed by the rising tide of scientific discoveries. A new ethos, or existential stance toward reality, united diverse participants into a broader intellectual movement sharing similar political ideals and social aims in a common cosmopolitan spirit spreading throughout the cities of Europe and extending to North America. ${ }^{5}$ This so-called 'republic of letters' was an inevitable consequence of growing public literacy augmented by the spread of popular literature, along with the growing popularity of public coffee houses ${ }^{6}$ and of debating societies and literary salons where thinkers of various tendencies gathered to converse on fashionable or pressing issues. These public intellectuals - the self-styled 'philosophists' (French: philosophes, with France at first being the social and intellectual heart of this tendency) - highlighted the rule of law and the need to introduce constraints upon arbitrary exercise of institutional power by kings, nobility, or priests. They taught democracy and equality, revolution and reform, cosmopolitanism and internationalism, scepticism and science - all in a heady mix of rationalist and social-political agendas that captured the imagination of both the leisured class and of a growing public middle class.

The basic components of various tendencies jostling together under the umbrella of this 'Enlightenment' (German: Aufklärung, French: Les lumières, Italian: Illuminismo) or 'Age of Reason' were grounded on unbounded faith in the primacy of critical reflection, confidence in the demonstrable physical laws of nature, and an 
optimistic utopianism in material progress through controlling nature and history. They embraced the following:

1. The universe is fundamentally rational and can be understood through the use of reason alone.

2. Truth can be attained by empirical observation, the use of innate human reason, and systematic doubt, while traditional authority (of monarchs, or the Church) is not to be preferred over experience.

3. All social and individual human life may be understood in the same way physical laws of the natural world are understood - they are subject to manipulation or engineering in the same manner that the natural world is subjected to human use, thus to 'instrumental reason'. Instrumental rationality refers to employing human reason as a tool to reach goals, rather than using reason to critically assess the value or end of goals. For the natural sciences, it denotes knowledge of natural processes with the potential for technically harnessing natural laws or manipulating physical properties and conditions of nature. In the social sciences, economics well exemplifies instrumental reason in that it investigates how economic laws constrain human activity, and seeks to manipulate those laws or conditions.

4. Human beings may be improved by education and developing their rational facilities.

5. Human history is largely a history of ascending material and rational progress: by developing scientific knowledge of the natural world along with the ability to manipulate the physical world through technology, by overcoming ignorance bred of superstitions and religions, and by mitigating human cruelty and violence through social improvements and government structures.

6. Religious and metaphysical teachings on transcendent values as the source and goal of human existence have no intrinsic place in the understanding of the physical as well as human realms (secularism).

7. The greatest human crimes were perpetrated in the name of religion and of God - so a fair, just, and productive society requires religious tolerance between differing Christian sects, and even (in the view of some) towards non-Christian religions.

These newly-formed 'philosophists' of the Enlightenment were convinced they had discovered a sure formula for perpetual human happiness. They sought to deliver individuals from political and religious restraints so that they could act freely in accordance with human nature. The formula promised that pursuit of unfettered self-interest would benefit society as a whole; while it also promised that unfettered human reason would produce sound moral judgments, liberated 
from the dogmatism and superstition of organised religion (Deism). Autonomous individual freedom encouraged the application of natural physical laws in shaping human activity and organisation. Material reality was accepted as the only reality, and natural laws affecting human society were deemed to be basically mechanistic. ${ }^{7}$ In their theories of human personality and development, and of social dynamics and organisation, Enlightenment thinkers departed from older religious and moral explanations of human behaviour and interactions towards an empirical analysis and mechanistic explanation of the laws of human activity and motives. Believing they now understood these scientific laws, the eighteenth-century rationalists were convinced they had found the secret of never-ending progress. ${ }^{8}$

Gray bluntly labels such belief in progress as a utopian 'myth' - portraying it as an inverted or sublimated act of faith deriving (unconsciously) from older Christian salvational teachings that were recast in a secular mould. He depicts secular culture as a "mutation of religious faith" being "a hidden re-birth of apocalyptic religious myth that is repressed in thought and emotion and shut off from conscious scrutiny". 9 As we shall see below, the consequences of this displacement from salvation in the Hereafter toward a perfect social and economic order in the here and now, continues to reverberate in our lives today.

The signatories of the French Declaration of the Rights of Man and of the Citizen, the American Declaration of Independence, the United States Bill of Rights, and the Polish-Lithuanian Constitution (3 May 1791) were all motivated by these Enlightenment principles. The French Revolution in 1789 was experienced in Europe as the most profound spiritual and intellectual crisis, when the sense of common purpose fostered by the Enlightenment gave way to divisive conflict. The assault undertaken by the philosophes against the old feudal order led to the long international battle fought by means of revolutions and dissenting political movements - from 1789 until 1939 into the present - between both liberal and socialist forces imbued with the Enlightenment heritage, and those forces of religious reaction, conservative prejudice and landed feudal privilege whose inspiration derived from what Isaiah Berlin termed the 'Counter-Enlightenment' ${ }^{10}$ The triumphalist Eurocentric view of history which maintains not only that the scientific and technological changes emanating from Europe resulting in the Industrial Revolution brought economic change throughout the world, but also gifted 'civilisation' to the rest of the world (thanks to Colonialism), was not effectively challenged until the mid twentieth century.

Understanding the natural world and humanity's place in it solely on the basis of instrumental rationality - while trivialising the experience of religious faith and relevance of transcendent values for human existence - was perhaps the outstanding feature of the Enlightenment project. Unfettered innate reason was promoted as the primary source and legitimacy for ethics, political authority, economic 'science' and 
social organisation. This prepared the way for the emergence of the contemporary 'physicalist' notion of reason as a brain function or 'mental event' at the basis of scientism. ${ }^{11}$ The foundation of modern Western political, economic, scientific and intellectual culture rests upon the Enlightenment - with its general hostility towards religion, promotion of secularity (separation of State from Church), and the privileging of applied reason for securing human freedom and material progress. The 'grand narratives' which enshrined those sweeping principles continued to hold sway during the nineteenth century which attempted to reconstitute a continuum of gradual progress in the new scientific paradigms of Positivism, Socialism and Evolutionism (Darwinism) taken to be truly 'modern'. In one sense, all of us moderns are children of the Enlightenment.

The devastating critique by thinkers of the Frankfurt philosophical school Max Horkheimer and Theodor Adorno in their seminal study Dialectic of Enlightenment, ${ }^{12}$ highlighted the 'dark' side of the Enlightenment project which fed into the revolutionary Reign of Terror of the Jacobins (1793-94) during the French Revolution, and appeared in the twentieth century in the cruel totalitarian excesses of fascism, as well as of Marxist socialism in Russia and then of Maoist China. In addition, by facilitating the dramatic spread of capitalism, there is the undeniable impetus which the Enlightenment endowed to European imperialism with all its injustices and oppression. Thus, from the French Revolution of 1789 through centuries of exploitation, war and imperial conquest - 'modernity' has remained entangled with bloodshed and terror.

Contemporary debates assessing the legacy of the Enlightenment have recently been magnified by conflicting evaluations issuing from the political left and from the fundamentalist as well as conservative right in Euro-American thought. The German social theorist Jürgen Habermas, one of the most eloquent defenders of the contemporary relevance of the Enlightenment project, pointedly asked: ${ }^{13}$

Enlightenment thinkers still had the extravagant expectation that the arts and sciences would promote not only the control of natural forces, but would also further understanding of the world and of the self, would promote moral progress, the justice of institutions, and even the happiness of human beings. The 20th century has shattered this optimism [...]. Should we try to hold on to the intentions of the Enlightenment, feeble as they may be, or should we declare the entire project of modernity a lost cause?

However, in the view of Horkheimer and Adorno, ${ }^{14}$

the scientific method of the Enlightenment may have originally intended to serve the ideals of human liberation in an assault upon religious dogma. Yet the power of scientific reason ultimately wound up being directed not merely against the gods, but all metaphysical ideas - including conscience and freedom - as well. 'Knowledge' became 
divorced from 'information', norms from facts, and the scientific method, increasingly freed from any commitment to liberation, transformed nature into an object of domination, and itself into a whore employed by the highest bidder.

In the more charitable positive evaluation: "the Enlightenment was always a movement of protest against the exercise of arbitrary power, the force of custom and ingrained prejudices, and the justification of social misery," ${ }^{\prime 15}$ and it remains essentially relevant to democratic and liberal impulses for Western thought today. But in the more radically negative evaluation: ${ }^{16}$

[...] all schools of contemporary political thought are variations on the Enlightenment project [...]. That project, though irreversible in its cultural effects, was self-undermining and is now exhausted. Fresh thought is needed on the dilemmas of the late modern age which does not simply run the changes on intellectual traditions whose matrix is that of the Enlightenment. This is so [...] because some of our dilemmas issue from aspects of the Enlightenment itself - in particular its assault on cultural difference, its embodiment of Western cultural imperialism as the project of a universal civilisation, and its humanist conception of humankind's relations with the natural world. This last element of the Enlightenment has been transmitted even to cultures which have modernized without Westernizing, and constitutes the West's only truly universal inheritance to humankind, which is nihilism.

This is indeed an unsparingly harsh critique of Enlightenment legacy. But Gray goes even further in his unrelenting unsentimental analysis, stripping naked the harmful delusions and arrogant hubris inflicted on our world over the past several decades including the ongoing financial crisis, and asking what path the orphans of the Enlightenment should now take.

\section{John Gray on Casino Capitalism and Missionary Politics}

A strong upholder of value-pluralism and self-described 'post-Christian unbeliever' Gray is a political philosopher of the old school deeply engaged with political economy, history, and social theory. He understands modernity from the multidisciplinary perspective of a post-liberal historicist view. Gray is controversial in the United Kingdom for having been an advocate for the New Right in the 1980s, and then crossing over to New Labour in the 1990s; yet now Gray sees the conventional political spectrum of conservatism and social democracy as passé. Since the 1990s he also attracted controversy for his position on value-pluralism linked to his interpretation of Isaiah Berlin's liberalism; ${ }^{17}$ and more recently for his strong criticism of neoliberalism and the global free market. He now defends a pluralist perspective where "the animating project is that of framing terms of harmonious coexistence 
among different cultures and traditions", seen as the end-phase of Enlightened modernity for a post-Christian liberal humanism. Gray has further criticised central currents in Western thinking including progress and humanism, and favours Green thought. He consistently forecasts that the twenty-first century shall be marked by wars over natural resources accompanied by civilisational dissonance. With the fall of the Iron Curtain, trans-national Jihadist attacks, and a coming anarchic global economy, the world will find itself facing many familiar conflicts that never went away but were only submerged: religious and ethnic enmities, ideological rivalries and divergent economic interests over resources, with the world awash in weapons.

His well-informed writing brims with up to date references, and he integrates ideas into the wider cultural and institutional conditions underlying political developments in Europe and Asia over the past two centuries. Gray's style is briskly invigorating, nuanced and ironic, at times boldly provocative and daring, exhibiting a consistent tendency to capture the political and social crux of key ideas, events, or thinkers. This undoubtedly leads him occasionally into oversimplification for the sake of dramatic effect, but this is a risk a writer takes when seeking to engage and persuade the reader. Rarely does he descend into polemic, although his US critics have dogmatically accused him of bias against American economic, political and cultural values. He continually invites the reader to think afresh about our world by questioning unexamined assumptions, engaging deeply with human history and experience fully conscious of the unfolding of ideas and their transformations.

Gray's starting point for reflection is that over the past several decades three world-historical events have occurred: collapse of the Soviet Union with ensuing economic and political transformations; the 11 September 2001 Jihadist attacks with its corollary US-led 'War on Terror' and military interventions into Asia; and the ongoing crisis of 'Free Market Capitalism' with ensuing global financial turmoil. Collectively these suggest the exhaustion of the Enlightenment project which initiated our present era of late-modernity. The rationale for this view is his understanding that these three seemingly unrelated developments are actually deeply rooted in the ethos of the Enlightenment, and draw nourishment from its ideals as they unfolded over the nineteenth century.

In 1998 Gray published False Dawn: The Delusions of Global Capitalism, wherein he argued that a single global market is primarily a political project (i.e. of the neoliberal financial elite), and asserted: "The free market is not [...] a gift of social evolution. It is the end-product of social engineering and unyielding political will." Five years later in 2003 he published a slim volume summarising his views on modernity, Al Qaeda and What it Means to Be Modern, in which he wrote:

The global free market is not the result of competition between different economic systems. Like the free market that was created in England in the mid-nineteenth century, it 
was established and maintained by political power. Unlike its English precursor, the global free market lacks checks and balances. Insulated from any kind of political accountability, it is much too brittle to last for long [...].

The global free market is the offspring of a marriage of Positivist economics with the American sense of universal mission. It was only in the last decades of the twentieth century that Positivist thought came to be associated with the defence of free markets. [...It] was the Positivist doctrine that economic efficiency is measurable in terms of productivity that gave the free market the authority of science. [...] The American free market was elevated to the status of a universal economic system. ${ }^{18}$ (see below for more on nineteenth-century Positivists)

Not everyone will agree with his assessment. In False Dawn Gray maintains that economic globalisation essentially represents the spread of new technologies worldwide, and may occur without necessitating a free market. By means of a concise comparison of several economic case studies of specific nation-states who took up economic liberalisation by opening to the global free market (South Africa, New Zealand, Argentina), he shows that uneven development within nations and between nations often ensues. He pays particular attention to transformations underway in Russia and especially China. He predicted that competitive currency devaluations, economic and political upheavals, and global shocks were unavoidable within the (then) current system.

Gray attacks "the political thought of the New Right for its fundamentalist conception of market institutions and its hubristic neglect of the human need for common life" which endanger liberal institutions and practice. ${ }^{19}$ Among the real effects for the developed economies of extensive 'marketisation' of society are high structural unemployment, falling wages for low-skilled workers, the growing reality of two-income families, along with high rates of incarceration and drug abuse. Gray concluded, presciently, that global capitalism is inherently unstable given that a global free market cannot self-regulate, and will inevitably fall apart. He wrote False Dawn during the Asian financial crisis of 1997, yet it offers serious reflection on the history of global capitalism since the nineteenth century, weaving into his argument many inter-related topics and themes such as post-Soviet shock therapy and considerations on East Asian economies.

Throughout his writings Gray reiterates several basic themes from differing contexts or considerations. Prominent among these are: the continuing reverberation of Enlightenment ideals of universalism and social progress within European political thinking over the past two centuries cutting across various ideological divides and political projects; and the utopian expectations animating historical movements of "political religion" as "projects of universal human emancipation". ${ }^{20}$ In False Dawn (ch. 1, p. 2) Gray aligned together several Enlightenment thinkers, 
including the influential English philosopher John Locke (1632-1704) and the German political historian and economist Karl Marx (1818-1883), on the basis of a common striving for a utopia where "a diversity of cultures [...] is a stage to a universal civilisation". Specific historical efforts to impose a "universal civilisation" included Victorian era England, the Soviet Union, and currently the United States as "the last great power to base its policies on this enlightenment thesis" - namely, as reflected in the 'Washington Consensus'. He traces the Enlightenment project of universal emancipation and a universal civilisation through successive incarnations, tying together movements, thinkers and ideas. Maoism is portrayed as "a modern western doctrine of universal emancipation", while the War on Terror is seen as "an Enlightenment crusade for universal democracy". ${ }^{21}$

Gray directly controverts the central Enlightenment thesis positing the uniformity of scientific and technological advance with social progress, i.e. the parallel posited by instrumental reason between natural physical laws and the laws of human moral activity: ${ }^{22}$

The belief that scientific advance engenders social progress suggests that science and ethics are alike, when in fact they are very different. Once it has been acquired and disseminated, scientific knowledge cannot now be lost; but there is no ethical or political advance that cannot be reversed. [...] There may be some types of society in which science cannot flourish, but there is no one type that it advances. Any society that has the power of invention is modern. Not all societies can be modern. That does not mean that only one kind can be.

So there is no compelling reason to assert that science is bound to yield a single view of our world; "it is only a metaphysical faith in the uniformity of Nature that supports the idea that one day a single view of things will be left alone in the field". Gray connects this observation with the impact of ideas of the Positivists upon the recent American neoliberal view that the free market is the inevitable model for financial activity to be adopted globally. ${ }^{23}$

The Positivists believed that modern societies would be the same everywhere. Most people believe the same today. The truth is that we cannot know in advance what it means to be modern. If the modern period is simply the mix of things produced by accelerating scientific advance, modern societies will vary widely and unpredictably. This is the true meaning of globalisation. In the sense in which it is now used by politicians, it refers to the global free market that was constructed at the end of the Cold War. The global free market is a political construction not much more than a dozen years old.

Believing that one way of life is best for all of mankind and viewing history as the struggle to achieve it, Marxism and neoliberalism are post-Christian cults. Beyond Christendom, no one has ever imagined that 'world communism' or 'global 
capitalism' could be 'the end of history'. The Positivists believed that with the advance of knowledge humanity would come to share the same values; but this is because they had inherited from Christianity the belief that history is working to a finale in which all are saved. Positivism is a doctrine of redemption in the guise of a theory of history. We laugh at the enthusiasm of these prophets of modernity (the Positivists St Simone and Auguste Comte) for the pseudo-science of phrenology. Yet free market economics is no different. Like its predecessor, 'scientific socialism', it rests on a spurious claim to knowledge of the future.

Gray assumes, of course, that readers are acquainted with the naïve thesis advanced by the (former) neo-conservative Francis Fukayama on the 'End of History' which trumpeted the victory of American capitalism over totalitarian communism, and proclaimed Western liberal democracy to be the ultimate form of government and an American-led global free market the perfect financial order. Yet Gray's point is well taken, if somewhat overdrawn or exaggerated to provide effect - 'post-Christian cults'. Next, he invokes his conviction on the reality of value-pluralism (the ethical theory positing a multiplicity of incommensurable values) as an indispensable constituent of his view of liberal modernity: ${ }^{24}$

The modern myth is that with the advance of science one set of values will be accepted everywhere. Can we not accept that human beings have divergent and conflicting values, and learn to live with this fact? [...] We can imagine a future in which each country would be free to find its own version of modernity. [...] Societies with widely diverging histories and values would be allowed to develop correspondingly divergent economic systems. If countries sought to establish alternative monetary systems, they would be free to do so. Projects such as Islamic banking may not be fully practicable; but they can hardly be as unrealistic as the madcap schemes imposed on many countries by the IMF and the World Bank.

Gray's thinking tends to exercise a liberating effect by confronting us with juxtaposed ideas we normally do not associate with each other. Although not everything he states is equally convincing, there is undoubted utility in being exposed to viewpoints one rarely hears from Anglo-American circles. We will leave him now with a final citation taken from his discussion on the post-Soviet economic breakdown. ${ }^{25}$

Western liberal institutions not only have no universal claim in theory but also are often flawed in practice; except where their underlying cultural and political traditions are themselves European, the post-communist countries have good reason to seek to develop new, non-Western institutions of their own. The thesis that the institutions of Western civil society are functionally indispensable to the success of a modern economy, though at first sight plausible, is theoretically and historically groundless. 


\section{Conclusion and Recommendations}

A lack of awareness of the past undermines our ability to make sense of the present and chart a future course. In sighting a way beyond the current impasse, seeking sound alternatives to the civilisational crisis we find our planet in, we must keep in mind both the weight of historical unfolding and the notions of what human motives and fulfilment truly comprise. Neoliberal marketisation of societies may be understood as serving a political project whose concern is the profits of a narrow elite not possessed of any binding obligation to states or to societies, let alone to humanity. Economic systems and orders arise out of specific social relations and mirror a definite image of what the human is - an anthropology. ${ }^{26}$ Alternatives spell choices, and many alternatives are being propounded with the dawning realisation of the severity of the world system crisis. Many of these proposals complement and converge with one another, others contradict or oppose. What is not evident is how successfully Muslim thinkers have elaborated coherent alternatives that convey a veritable Islamic position.

The shifts and realignments that the global market turmoil triggers have given wiseacres and pundits cause for alarm over the close, or the opening, of a stage in history. Fareed Zakaria, Newsweek International's editor, does not concede the United States will be obliterated by emerging power reconfigurations:

America will be the most powerful economy in the world for the foreseeable future and the West will still be important [...] but it will have to share that power with countries, cultures and civilisations it has traditionally dominated, colonised and looked down on, and that re-balancing of the world will be the great story of our time. ${ }^{27}$

The historian Niall Ferguson is more ambivalent and questions the viability of the neoliberal capitalist model of market institutions: "The question really is whether an alternative model will take the place of the Western financial model." ${ }^{28}$ John Gray in his thought-provoking manner gives one pause for thought:

We live today amid the dim ruins of the Enlightenment project, which was the ruling project of the modern period. [...] Contrary to the hopes which buoyed up Enlightenment thinkers throughout the modern period, we find at the close of the modern age a renaissance of particularisms, ethnic and religious. [...] Within Western cultures, the Enlightenment project of promoting autonomous human reason and of according to science a privileged status in relation to all other forms of understanding has successfully eroded and destroyed local and traditional forms of moral and social knowledge; it has not issued in anything resembling a new civilization [...]. Where modernization has been achieved without the destruction of the traditional culture, and without the incursion of the illusions of the Enlightenment [...] It is reasonable, and in fact imperative, to resist 
Western demands for the development of social and economic institutions on a bankrupt Western model. ${ }^{29}$

In closing, policy makers, officials, economic and financial advisers, and all thinking persons seeking to understand what drives the present, must give intelligent and sustained attention to the search for viable alternatives which effectively meet human needs and serve timeless values - whether they be Chinese or Islamic or Socialist. They must pay serious attention to:

- exposing and training mid-level economic, planning and social system officials in the history and theory of capitalist World System development;

- paying close attention to advancing informed and intelligent formulations of social and economic institutions for sustainable development that mirror their own specific cultural legacy and values;

- devoting meaningful material and human resources to forging networks with neighbouring nations and societies whose experience and assets can provide real help and assistance in these tasks, and thereby promote regional solidarity, self-reliance, de-linkage from the dominant Centre, and genuine democratic reform and progress.

\section{Notes}

1. Iran - a major oil producer - announced in late September 2009 that its foreign currency reserves would henceforth be in euros.

2. For an overview of his work see Gerald M. Meier and Dudley Seers (eds), Pioneers in Development (New York: Oxford University Press for the World Bank, 1984) and Fouhad Nohra, Théories $d u$ capitalisme mondial (Paris: L'Harmattan, 1997).

3. For one of his most recent works see Amiya Kumar Bagchi, Perilous Passage: Mankind and the Global Ascendancy of Capital (London: Rowman and Littlefield Publishers, 2005).

4. His most recent work is The Idea of Justice (London: Allen Lane, 2009).

5. For orientation on Enlightenment values at the basis of modernity, see e.g. Jonathan Israel, Radical Enlightenment: Philosophy and the Making of Modernity, 1650-1750 (Oxford and New York: Oxford University Press, 2001); Thomas Munck, The Enlightenment: A Comparative Social History 1721-1794 (London: Arnold, 2000); Lewis Hackett, "The Age of Enlightenment: The European Dream of Progress and Enlightenment" [1992], available online at http://history-world.org/age_of enlightenment.htm (accessed on 12 October 2009); Isaiah Berlin (ed.), The Age of Enlightenment: The 18th Century Philosophers (London: Plume, 1984). An influential yet oft-critiqued study of socio-cultural change inaugurated by the Enlightenment is Jürgen Habermas, The Structural Transformation of the Public Sphere, transl. Thomas Burger with the assistance of Frederick Lawrence (Cambridge MA: MIT Press, 1989).

6. On the importance of coffee in the social process of the Enlightenment, see Brian Cowan, The Social Life of Coffee: The Emergence of the British Coffeehouse (New Haven: Yale University Press, 2005). Coffee as a popular beverage spread to Western Europe from Arab Ottoman territories where the coffeehouse first appeared. For the Islamic background, see the excellent study by Ralph S. Hattox, Coffee and Coffeehouses: The Origins of a Social Beverage in the Medieval Near East (Seattle: University of Washington Press, 2000). 
7. An assumed correlation in the uniformity of natural laws with the principles governing human social and political activity - a chief feature of Enlightenment thought and its approach to instrumental reason - has been critiqued as a totally gratuitous assumption; see esp. Paul Feyerabend, Farewell to Reason (London and New York: Verso, 1987), ch. 3 on relations of theoretical knowledge with historical traditions on the development of modern science (I am indebted to the late Professor Syed Hussein Alattas for this reference). See also J. Gray, Al Qaeda and What it Means to Be Modern (London: Faber and Faber, 2003), 109.

8. John Gray, Voltaire and Enlightenment (London: Orion, 1998), points out that not all the Enlightenment philosophes unequivocally adhered to belief in inevitable universal progress.

9. Idem, Al Qaeda, 116; idem, "The Myth of Progress", New Statesman, 9 April 1999, available online at http://www.newstatesman.com/199904090020 (accessed on 12 October 2009). In his Black Mass: Apocalyptic Religion and the Death of Utopia (London: Allen Lane, 2007), Gray explores more fully this repressed dimension of modern politics as "a chapter in the history of religion" (p. 2) with pernicious consequences and remains largely ignored by contemporary establishment thought. Previously, certain thinkers such as Heinz Heimsoeth, The Six Great Themes of Western Metaphysics and the End of the Middle Ages, transl. R.J. Betanzos (Detroit: Wayne State University Press, 1994; German original 1922) made parallel observations.

10. See Darrin M. McMahaon, Enemies of the Enlightenment: The French Counter Enlightenment and the Making of Modernity (Oxford: Oxford University Press, 2001).

11. More details in Karim D. Crow, "Islam and Reason", Al-Shajarah [Kuala Lumpur] 8, no. 1 (2003), 109-37.

12. Max Horkheimer and Theodor Adorno, Dialektik der Aufklärung (Amsterdam: Querido, 1947), English transl. Edmund Jephcott (Stanford CA: Stanford University Press, 2002). This work, contextualised in a reaction to National Socialism, has had a major effect on twentieth-century philosophy, sociology, culture and politics, and is still being actively discussed today. Further, consult Gray, Black Mass, ch. 2 "Enlightenment and Terror in the Twentieth Century", 36-73.

13. Jürgen Habermas, "Modernity versus Postmodernity", New German Critique 22 (Winter 1981), 3-14.

14. Citing here the paraphrase by Stephen E. Bronner, "Interpreting the Enlightenment: Metaphysics, Critique, and Politics", Logos 3, no. 3 (Summer 2004), also available online at http://www. logosjournal.com/issue_3.3/bronner.pdf (accessed on 12 October 2009). He reviews post-9/11 contestations of the Enlightenment legacy by both the fundamentalist right and radical left.

15. Bronner, "Interpreting". Bronner seeks to salvage the Enlightenment legacy as a necessary precondition for progressive politics today. In contrast, see the radical critique offered by John Gray, Enlightenment's Wake (London and New York: Routledge, 1995; repr. 2007 in the series 'Routledge Classics', with a new introduction by the author), whose very title posits the eclipse or obsolescence of the Enlightenment project.

16. Gray, Enlightenment's Wake, ix; see also ch. 10 "Enlightenment's Wake", 215-76.

17. Gray, Enlightenment's Wake, ix; therein see also his chapter "From Post-Liberalism to Pluralism", 196-214. Enlightenment's Wake is the culmination of Gray's series of three previous works on political philosophy and the scope and limits of liberalism: Liberalisms: Essays in Political Philosophy (London and New York: Routledge, 1989); Post-Liberalism: Studies in Political Thought (London and New York: Routledge, 1993); and Beyond the New Right: Markets, Government and the Common Environment (London and New York: Routledge, 1993) - see e.g., ch. 4 "An Agenda for Green Conservatism" as a critique of the project of a global free market in the context of proposals for global free trade.

18. Gray, Al Qaeda, ch. 4 "A Very Short History of the Global Free Market" (48-50). He traces the Positivists' influence mainly to the impact of Comtean ideas - the French sociological positivist Auguste Comte died in 1857 - reaching American social science in the late twentieth century through the Vienna Circle. On p. 49 we read: "American economists followed the Positivists in thinking that productivity is the best measure of economic efficiency, but lacked their understanding that productivity alone does not make a humanly acceptable economy". 
19. Gray, Enlightenment's Wake, viii; his views are developed in detail in ch. 3 "The Moral Foundations of Market Institutions".

20. Gray, Al Qaeda, 116.

21. Gray, Black Mass, 192.

22. Gray, Al Qaeda, 110; 109 for the citation immediately following.

23. Gray, Al Qaeda, 112, 104-6. On p. 105, Gray cited the remark of the philosopher Stuart Hampshire in 'Justice is Strife', who stated: "The Positivists believed that all societies across the globe will gradually discard their traditional attachments $[\ldots]$ because of the need for rational, scientific and experimental modes of thought which a modern industrial economy involves. [...] We now know there is no 'must' about it and that such theories have a predictive value of zero."

24. Gray, Al Qaeda, 113-14.

25. See Enlightenment's Wake, viii-ix; see also ch. 5, "The Post-communist Societies in Transition", 51-95. This essay first appeared as his monograph, The Post-Communist Societies in Transition: A Social Market Perspective (London: February 1994). Previous to this, Gray had forecast the likely meltdown of the principal Western models in his seminal article "From Post-Communism to Civil Society: The Reemergence of History and the Decline of the Western Model", Social Philosophy and Policy, Liberalism and Economic Order 10, no. 2 (Summer 1993), 26-50. Gray's critique of 'shock therapy' provoked a response by Jeffrey Sachs, Understanding Shock Therapy (London: Social Market Foundation, 1994). For an account of this debate between Gray and Sachs, see Robert Skidelsky, The World After Communism (London: Macmillan, 1995), 166-72.

26. See in particular Ali El Kenz, "An Anthropological View on the Crisis," in The World Crisis and Beyond, 126-38, available online at http://www.tni.org/sites/tniclone.test.koumbit.net/files/ download/beyondthecrisisreader.pdf (accessed on 10 January 2010), and Wendy Brown [Professor of political science, University of California Berkeley], "Neoliberalism and the End of Liberal Democracy", in her Edgework: Critical Essays in Knowledge and Politics (Princeton: Princeton University Press, 2005), 37-59.

27. Helena Meriman, "The End of the Western Economic Era?" (BBC World News, 24 September 2009).

28. Ibid.

29. Gray, "Enlightenment's Wake", in Gray, Enlightenment's Wake, 216-18. 